\title{
DRYING AND STORAGE OF CORN GRAINS FOR ETHANOL PRODUCTION IN BRAZIL
}

\section{DRYING AND STORAGE OF CORN GRAINS FOR ETHANOL PRODUCTION IN $B R A Z I L$}

\section{Paulo Carteri CORADI ${ }^{1}$; Lélia Vanessa MILANE ${ }^{2}$, Lucas Jandrey CAMILO ${ }^{3}$; Maria Gabriela de Oliveira ANDRADE ${ }^{3}$}

1. Professor, PhD., Universidade Federal de Santa Maria-UFSM, Cachoeira do Sul, RS, Brazil. paulocoradi@ yahoo.com.br; 2. Graduate Student, Universidade Federal de Mato Grosso do Sul-UFMS, Chapadão do Sul, MS, Brazil; 3. Undergraduated Student, Universidade Federal de Mato Grosso do Sul-UFMS, Chapadão do Sul, MS, Brazil

\begin{abstract}
The aim of the present research was to evaluate the effects of drying air temperature and storage conditions used in Brazil on the quality of corn grains (Zea mays L.) for ethanol production. The experiment was set up in a completely randomized design in a $(3 \times 2 \times 2)$ factorial arrangement (drying air temperatures of 80,100 and $120{ }^{\circ} \mathrm{C}$ vs. ambient storage conditions of $23{ }^{\circ} \mathrm{C} / 60 \% \mathrm{RH}$ and cooled to $10^{\circ} \mathrm{C} / 40 \% \mathrm{RH}$ vs. storage time of zero and six months). The corn grains were harvested with a water content of $18.0 \%$ (w.b.). Then, they were dried in a convection/forced-air oven at different temperatures, until water content reached $12 \%$ (w.b.). After that, the grains were stored. It was concluded that the increase in drying air temperature reduced lipid content and starch percentage, decreasing ethanol yield to $38.74 \mathrm{~L} \mathrm{ton}^{-1}$ of grains. Storage under refrigeration at $10{ }^{\circ} \mathrm{C}$ was favorable for the maintenance of lipid levels $(+2 \%)$, starch percentage $(6 \%)$ and ethanol yield (33 L ton ${ }^{-1}$ of grains). Thus, considering production conditions and weather in Brazil, grains should be dried at air temperatures up to $80{ }^{\circ} \mathrm{C}$, and storage must be performed under refrigerated air up to $10{ }^{\circ} \mathrm{C}$ for quality assurance of maize grains in the dry season and, therefore, increased ethanol production in the industry.
\end{abstract}

KEYWORDS: Biofuels. Industry. Production. Zea mays L.

\section{INTRODUCTION}

Maize (Zea mays L.) is grown worldwide. It is native to Central America and its economic importance is evidenced by the various forms of use, whether in animal or human consumption (FAO, 2012). Brazil is among the three largest producers of maize, having produced 72 million tonnes in the last harvest (ABIMILHO, 2014). Given Brazil's huge productive capacity, quality products have to be offered to the market; therefore, the practices adopted from harvest to storage have to be the most adequate and safe in order to avoid losses and preserve the products' properties (CORADI et al., 2015). Only $15 \%$ of the world production of maize is intended for human consumption while the other $85 \%$ is intended for animal feed, i.e. animal nutrition accounts for the great demand for maize, as it is a traditional energy source of formulations (FAO, 2012).

With the advent of flexible fuel engines, an innovative technology introduced in 2003, and the growth of Brazil's automobile industry, the scenario has changed: ethanol became an indispensable product in the fuel market in Brazil, despite the constant price fluctuations faced by the alcohol industry and consumers in periods of harvest and fallow, respectively (GOLDEMBERG et al., 2008).
Concomitantly, the incorporation of new areas for production of energy from agriculture has occurred without competition against food farming. There is great availability of land with degraded pastures, where the inclusion of sugar cane can also benefit cattle farmers by increasing the profitability of their farms and improving soil fertility (GOLDEMBERG et al., 2008).

Brazil and the United States are world leaders in ethanol production (HETTINGA et al., 2009). World production of ethanol is approximately 13.5 million gallons. Brazil accounted for $33.3 \%$ of this volume, producing alcohol from sugarcane, while the United States have produced $36.3 \%$ from maize (FAO, 2012; DINNEEN, 2015). In spite of instabilities and following the path of technological innovation, the sugar cane industry has introduced, into the Brazilian market, ethanol produced from industrial processing of maize. However, there are some concerns that could influence the decision to implement, in Brazil, a production unit of ethanol based on maize grains. For example, the postharvest sector, precisely the drying and storage of grains, because maize is a crop produced in two seasons of the year and, therefore, grains would need to be stored in order to meet the demands of ethanol production. 
During drying, the use of high temperatures can compromise the final quality of the product. The use of higher mass temperatures of $60{ }^{\circ} \mathrm{C}$ during drying produces starch of low viscosity and yield in the extraction process by wet grinding and dried corn from high moisture (28-30\%) at temperatures above $82{ }^{\circ} \mathrm{C}$ also They have low oil yield and reduced protein content (BEMILLER; WHISTLER, 2009).

The grain storage in inappropriate conditions results in an increase in lipid oxidation and the content of free fatty acids, forming a complex with the helical amylose or reducing the length of the long chains of amylopectin, altering the physical and nutritional properties of grain and its end products (HASJIM et al., 2010). The storage grains refrigerated system is an alternative to maintaining product quality because it reduces the water activity reduces the respiratory rate of the grains, and also retards the development of insect pests and this microflora, regardless of weather conditions region (RIGUEIRA et al., 2009), allowing storage for longer periods of time. However, there are still studies for determining the safe storage temperatures for different grain moisture levels which ensure the final quality technological product.

The lack of storage infrastructure in Brazil and the use of inadequate techniques would result in greater quantitative and qualitative losses of grains, thus directly affecting ethanol production. Thus, the objective of the present study was to evaluate the effects of drying air temperatures $(80,100$ and 120 $\left.{ }^{\circ} \mathrm{C}\right)$ and storage conditions $\left(23{ }^{\circ} \mathrm{C} / 60 \% \mathrm{RH}\right.$ and 10 ${ }^{\circ} \mathrm{C} / 40 \% \mathrm{RH}$ ) used in Brazil on the quality of maize (Zea mays L.) grains and on the industrial yield of ethanol.

\section{MATERIAL AND METHODS}

The research was conducted at the Federal University of Mato Grosso do Sul (UFMS), Campus Chapadão do Sul (CPCS), in the Laboratory of Grain Post-harvest, and in the Ethanol Laboratory of the USIMAT processing plant, located in the town of Campos de Julio, state of Mato Grosso, Brazil. The experiments were set up in a completely randomized design in a $(3 \times 2 \times 2)$ factorial arrangement (drying air temperatures of 80,100 and $120{ }^{\circ} \mathrm{C}$ vs. ambient storage conditions of $23{ }^{\circ} \mathrm{C} /$ $60 \% \mathrm{RH}$ and cooled to $10^{\circ} \mathrm{C} / 40 \% \mathrm{RH}$ vs. storage time of zero and six months). Data were subjected to analysis of variance, and the effects of the treatments were evaluated by the F-test and, when significant, they were submitted to regression and polynomial analysis (Figure 1).

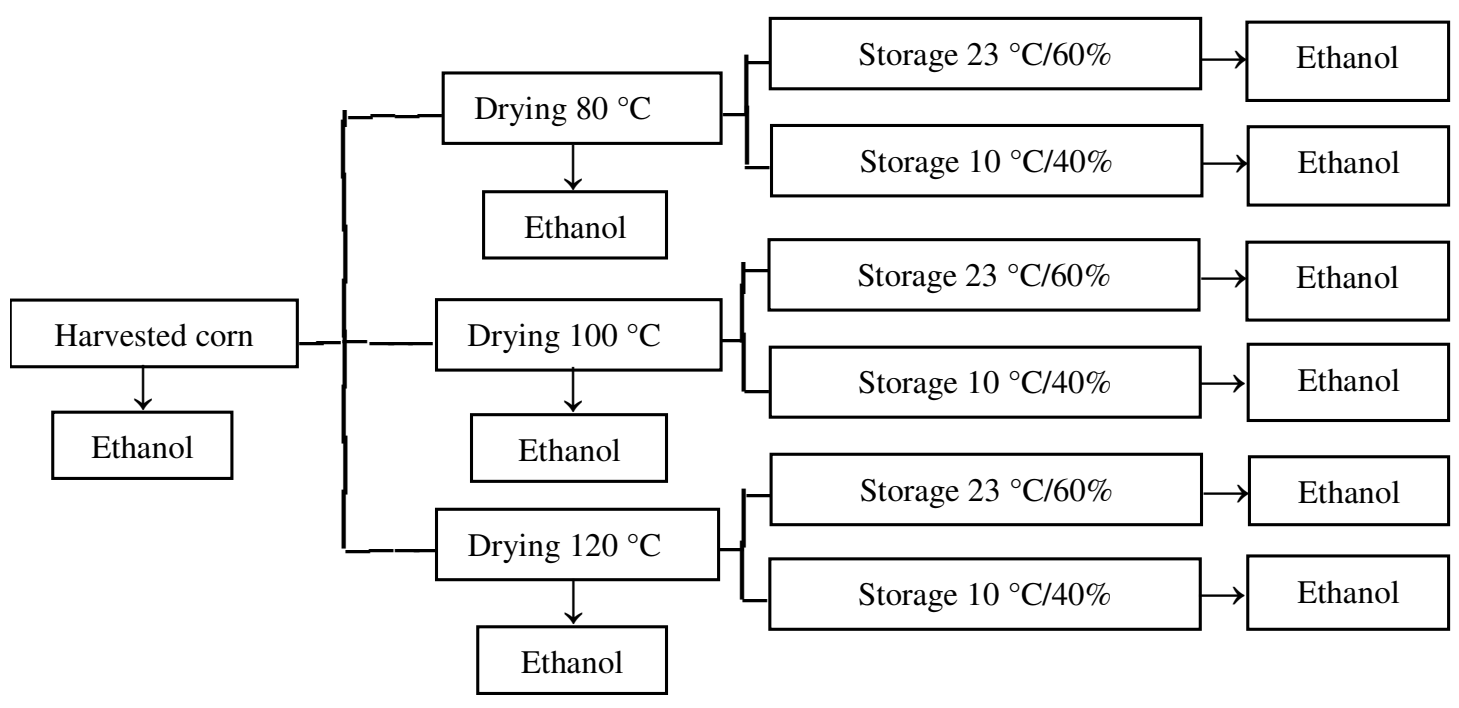

Figure 1. Flowchart of experimental design.

The maize grains used in the experiment were classified as hard, according to MAPA/Brazil, as shown in Figure 2. 

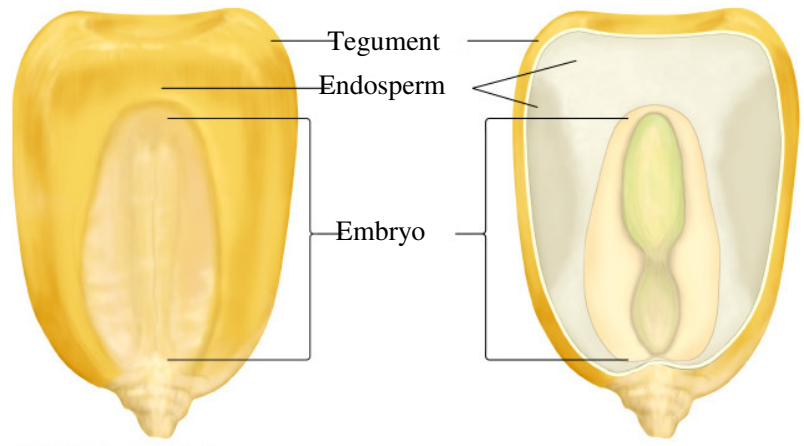

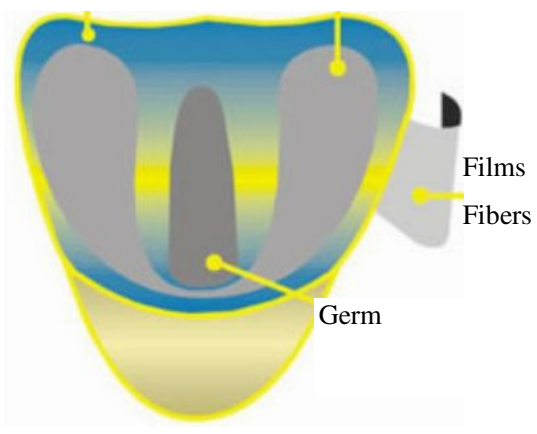

Figure 2. Structure of corn grains.

The maize grains were harvested randomly, and their water content was $18 \%$ (w.b.). Impurities and damaged grains were separated manually. Then, they were dried in a convection/forced-air oven at 80,100 and $120^{\circ} \mathrm{C}$, until water content decreased to $12 \%$ (w.b.). The temperature of the grain mass $(40 \pm$ $2{ }^{\circ} \mathrm{C}$ for the temperature of the air $80{ }^{\circ} \mathrm{C}, 44 \pm 2{ }^{\circ} \mathrm{C}$ for the temperature of the air of $100{ }^{\circ} \mathrm{C}, 49 \pm 2{ }^{\circ} \mathrm{C}$ for the temperature of the air $120^{\circ} \mathrm{C}$ ) was monitored during drying when the mass was removed from the oven for weighing, using a mercury thermometer. Three replicates were performed for each drying air temperature, and $2 \mathrm{~kg}$ of maize grains were used for each replicate. Then, the grains were stored in an environment at $23{ }^{\circ} \mathrm{C}\left(18^{ \pm} 2{ }^{\circ} \mathrm{C}\right.$ of the grains mass $)$ and one refrigerated environment at $10{ }^{\circ} \mathrm{C}\left(8^{ \pm} 2{ }^{\circ} \mathrm{C}\right.$ of the grains mass), for six months. At zero and six months of storage, evaluations were made of water content of the grains, physical classification, lipid content, starch percentage and ethanol yield.

Water content $(\%)$ was determined by the standard oven method, $105 \pm 5{ }^{\circ} \mathrm{C}$ for $24 \mathrm{~h}$ with three replicates, as recommended (AOAC, 2000). The assessment of physical quality of maize grains was performed with a simple 250 -gram sample. The sample was passed through a sieve with circular holes, with five millimeters in diameter, according to Normative Ruling $\mathrm{n}^{\circ}$. 60 of 22 December 2011, and the classification of maize introduced by the Ministry of Agriculture, Livestock and Supply, valid as of July 2012 (BRAZIL, 2012). Grains with physical modifications were separated and weighed. Measurements were made of percentage of damaged, whole, broken, cracked, musty, fermented, burned, and sprouted grains, as well as foreign matter and impurities. The results were compared with the standard classification table (BRAZIL, 2012) (Table 1). Thus, corn, was classified as "type 1", "type 2", "type 3" and "offtype". The analyses of lipid content, starch content and ethanol yield were performed at the Laboratory of the ethanol processing plant of the state of Mato
Grosso (USIMAT), located in the town of Campos de Júlio.

Starch content was determined with a total of $0.10 \mathrm{~g}$ of the ground sample $(1.0 \mathrm{~mm})$ was added in $20 \mathrm{~mL}$ test tubes, and $15 \mathrm{~mL}$ of the sodium acetate buffer solution $(\mathrm{pH}=5.00 \pm 0.05$ at $0.1 \mathrm{~mol}$ $\mathrm{L}^{-1}$ ) and $25 \mu \mathrm{l}$ of enzyme $\alpha$-amylase (Novozymes, Termamyl 2x) were also added. All test tubes were homogenized with a shaker and placed in a water bath at $100{ }^{\circ} \mathrm{C}$ for one hour; during this time, they were homogenized with incubation for 10,30 and 50 minutes. After the period of one hour, the tubes were removed from the water bath and remained on the bench until ambient temperature. Then, $0.5 \mathrm{~mL}$ of solution was added, containing 100 units of the enzyme amyloglucosidase $\mathrm{mL}^{-1}$ (Sigma - Aldrich). The tubes were agitated again and placed in a water bath at $60^{\circ} \mathrm{C}$ for two hours; they were agitated after incubation for one hour. After this period, the tubes were removed from the water bath and left on the bench until ambient temperature (BACHKNUDSEN, 1997).

The mixture was transferred to Eppendorf tubes which were centrifuged at $5500 \mathrm{~nm}$ for 10 minutes at a temperature of $10{ }^{\circ} \mathrm{C} .10 \mu \mathrm{l}$ of the supernatant of each tube was pipetted and transferred to test tubes containing $1 \mathrm{~mL}$ of Glucose GOD/PAP stable liquid kit at a 1:100 dilution. After 10 minutes of reaction at $37{ }^{\circ} \mathrm{C}$, reading was performed in a spectrophotometer (Shimadzu UV$1601 \mathrm{PC}$ ) at $510 \mathrm{~nm}$ (BACHKNUDSEN, 1997). For each test, a sample of corn meal and a sample of sweet corn were used. To avoid overestimation of starch content because of contamination with glucose, $0.10 \mathrm{~g}$ of the sample was weighed and transferred to $20 \mathrm{~mL}$ test tubes and $15 \mathrm{~mL}$ of deionized water was added. The mixture was left in the tubes for four hours, with agitation every 30 minutes. After this period, the content was transferred to Eppendorf tubes and centrifuged. Then, the same steps described above were followed. The value obtained after the reading of 
glucose was subtracted in the values found for starch in the samples (BACHKNUDSEN, 1997).

Lipid content was determined according to the method by AACC-30-20 (AACC, 1995). Oil extraction was performed with a Soxhlet extractor, using hexane as a solvent. The samples were milled before being taken to the extractor. In the process of oil extraction, $5 \mathrm{~g}$ of the sample of maize grains were weighed and then placed on filter paper, forming a cartridge and preventing the mixture of the material with the solvent. After that, the cartridge was placed within the container with $150 \mathrm{~mL}$ of hexane, and left in the extractor at a temperature of $70{ }^{\circ} \mathrm{C}$ for 4 hours. After the sample was taken out of the extractor, the filter paper and the residue were discarded, while the oil sample and the hexane were placed in a rotary evaporator. Water was heated at a temperature of $70{ }^{\circ} \mathrm{C}$ in the evaporator, and the solvent was evaporated into the condenser, which was then stored in a bottle. After the hexane was removed from the sample, the recipient with oil was taken to the greenhouse, where it remained for 24 hours at a temperature of $105{ }^{\circ} \mathrm{C}$. The solvent was totally removed from oil for quantification.

For the analysis of ethanol, four hundred grams of maize grains were milled, in roll mills; starch gelatinization was then performed by heating in water, thus favoring the action of enzymes for saccharification. Hydrolysis occurred during saccharification, converting starch into fermentable sugars. Enzymes were added for catalysis to carry out the process of hydrolysis. The enzyme $\alpha$ amylase was added to break the starch and produce dextrose, while maltose was produced by $\beta$-amylase. Fermentation was carried out with the mixture of inoculums of yeasts (Saccharomyces cerevisiae) for a period of three days, which was enough to produce alcohol. The must fermented with approximately $8 \%$ alcohol content was purified by distillation, with the components being separated by evaporation. In distillation, the mixture was heated to boiling (78.4 ${ }^{\circ} \mathrm{C}$ ) and the vapors were cooled until condensation. Based on the quantification of distilled ethanol, ethanol yield was determined for each tonne of maize grains (KWIATKOWSKI et al., 2006).

\section{RESULTS AND DISCUSSION}

Figure 3 are shown the mean values of the moisture content of corn kernels subjected to different drying conditions. It can be seen in Figure 3 that the time required for the corn kernels reach $12 \%$ (w.b.) was $0.5,1.5$ and 1.84 hours for drying temperatures of 120,100 and $80{ }^{\circ} \mathrm{C}$, respectively. It was also noted that with the increase in the drying air temperature increased to product water removal rate, indicating an increase in drying speed. As the drying process continues to equilibrium moisture content, drying representative curves are similar, differing only in the drying time.

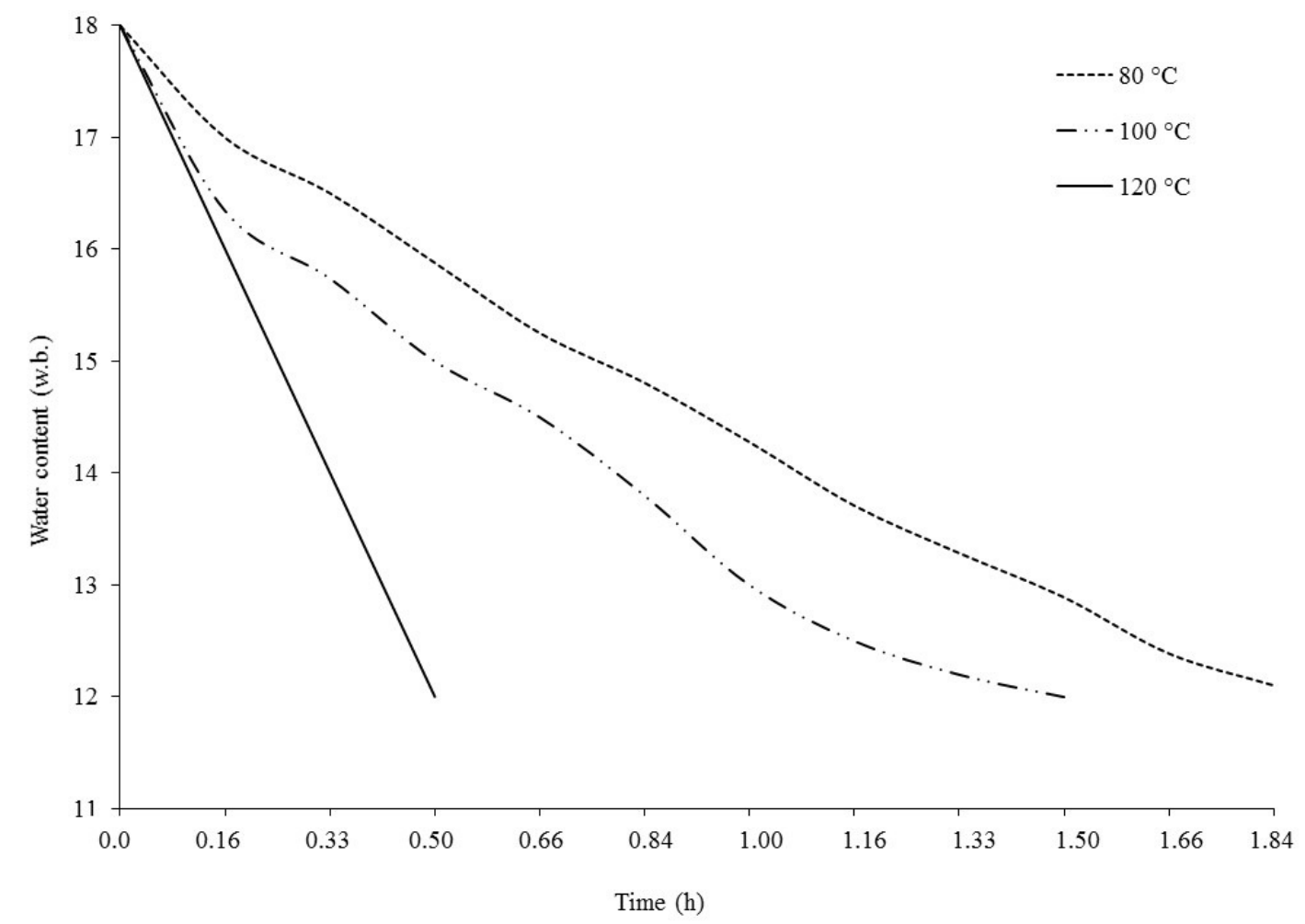

Figure 3. Curves drying of grains. 
Figure 4 and 5 shows the results of the physical classification of maize grains before and after drying and storage for six months. There was an increase of fermentation and rot grains after drying. The increase in physical damage and rot fermented grains were observed in the storage subjected to air condition temperature of $23{ }^{\circ} \mathrm{C}$ (Figure 5).

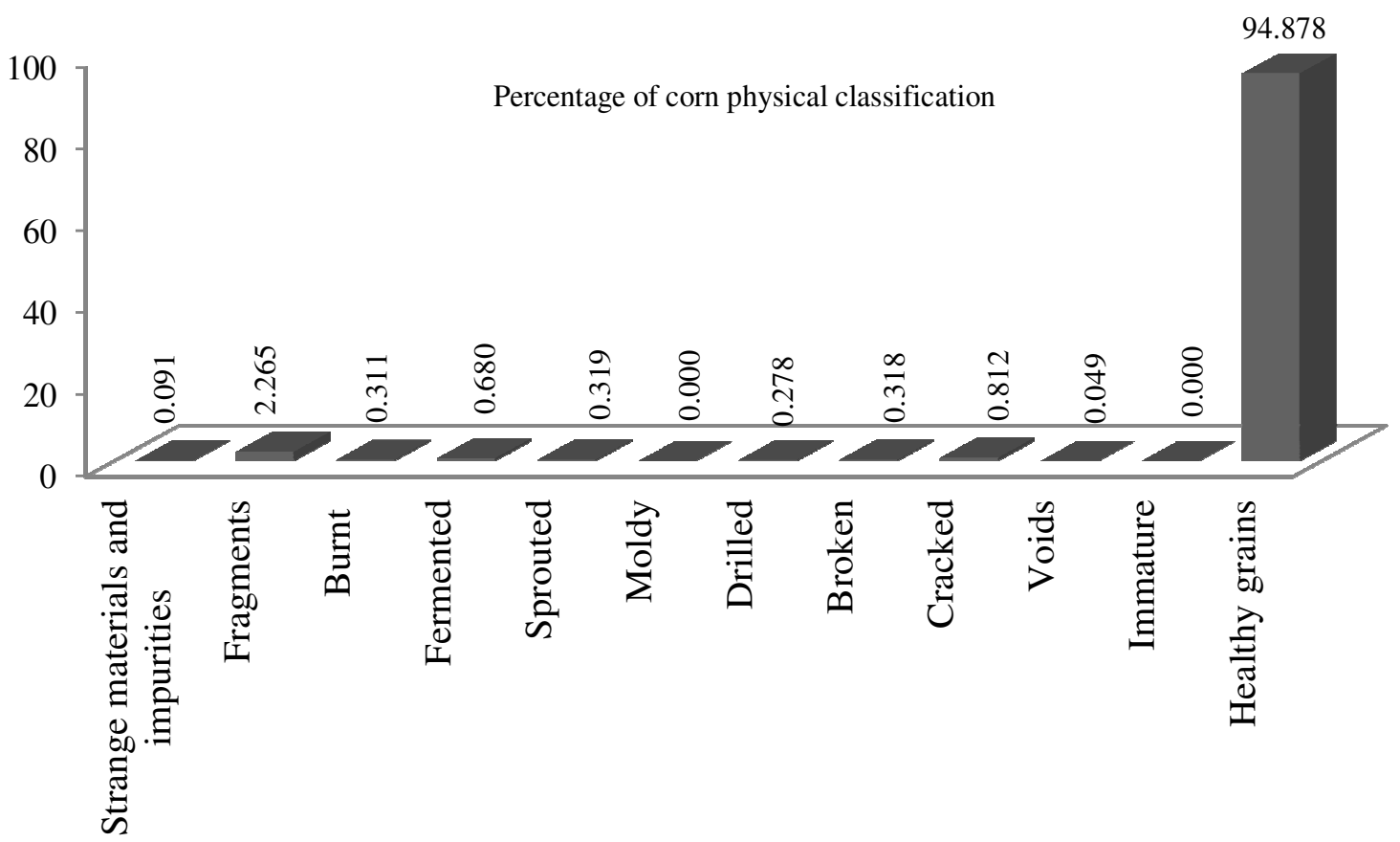

Figure 4. Initial physical classification of maize grains.

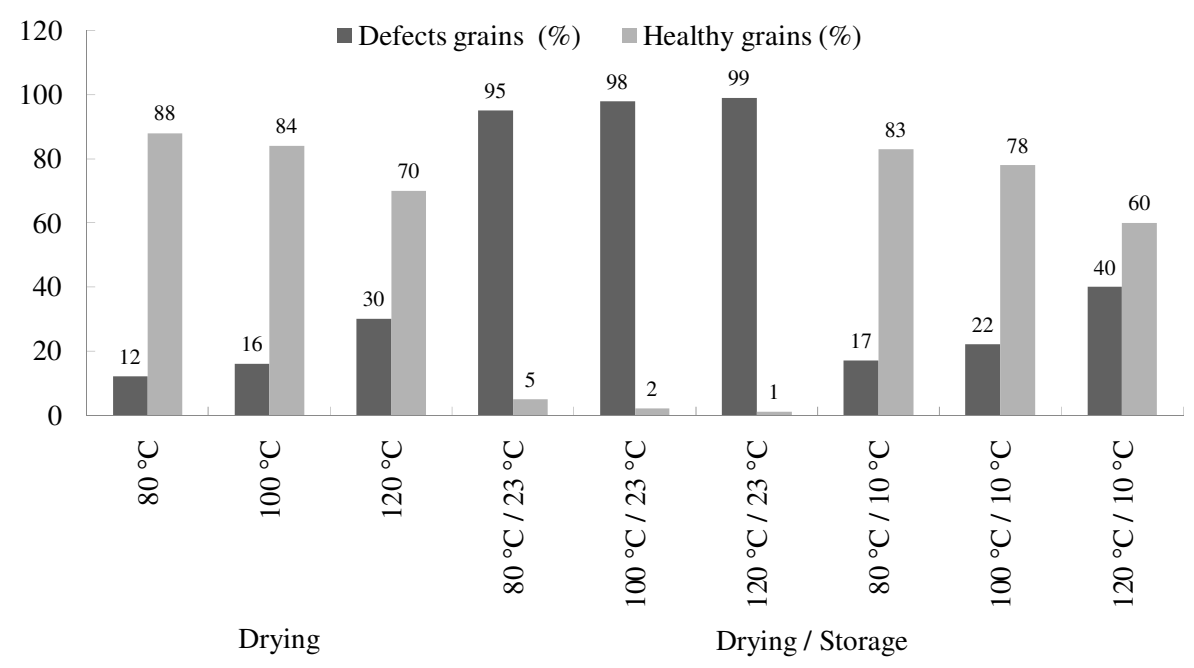

Figure 5. Physical classification of maize grains after drying and after storage.

According to the results, maize quality was rated as Type 1 (Table 1), and it was found that the effects of drying and storage affected the quality of the product. However, it should also be noted that there was a high rate of grains with serious defects (Figure 4 and 5), which did not meet the marketing standards for grains by MAPA (BRAZIL, 2012). 
Table 1. Quality attributes for classification of maze by type

\begin{tabular}{|c|c|c|c|c|c|}
\hline \multirow[t]{2}{*}{ Typification } & \multicolumn{2}{|c|}{ Damaged grains } & \multirow{2}{*}{$\begin{array}{l}\text { Broken } \\
\text { grain }\end{array}$} & \multirow{2}{*}{$\begin{array}{l}\text { Foreign matter and } \\
\text { impurities }\end{array}$} & \multirow[t]{2}{*}{ Rotten grains } \\
\hline & $\begin{array}{c}\text { Moldy and } \\
\text { burned grains }\end{array}$ & Total & & & \\
\hline Type I & 1.0 & 6.0 & 3.0 & 1.0 & 2.0 \\
\hline Type II & 2.0 & 10.0 & 4.0 & 1.5 & 3.0 \\
\hline Type III & 3.0 & 15.0 & 5.0 & 2.0 & 4.0 \\
\hline Off-Type & $>3.0$ & $>15.0$ & $>5.0$ & $>2.0$ & $>4.0$ \\
\hline
\end{tabular}

Brazil (2012).

The physical loss of grain quality after drying is explained by the way water was removed from the cell layers of the grains. During the drying process, moisture is initially extracted from the outer layers of grains, causing a gradient of humidity from the center of the grain to the edges. When this gradient is too large, internal tensions cause the grains to crack (COSTA et al., 2011; BRAZIL, 2012). For grains with higher initial water contents, the drying temperature should be lower, with use of higher temperatures only in cases of grain with lower water contents (WEBER, 2001; ULLMANN et al., 2010). When grains reach high temperatures, they are exposed to thermal damage that can reduce grain viability and vigor. To avoid loss of grain quality, the author recommends that grains should be artificially dried with temperatures up to $80^{\circ} \mathrm{C}$.

Severe grain drying with high temperatures is used in order to speed up the process and optimizing the equipment, while also reducing the development of fungi and toxins. However, these high temperatures can also damage the grains (ULLMANN et al., 2010; OLIVA et al., 2012). It was found that for storage in a natural environment, after six months, the maize grains considerably lost physical quality. Losses were greater for grains that suffered major thermal damage by high drying temperatures. However, in storage with artificial cooling, it was found that the grains maintained their physical quality, while minimizing the effects of drying. Water content is the most important factor in preventing deterioration of grains during storage. By maintaining the mass of grains with low levels of water and temperature, the effects of the attack of microorganisms and breathing can be mitigated. Temperature and relative air humidity are determinants in the process of loss of seed viability during storage and changes in the physical-chemical quality of the product and, in comparison with the by-products (LEE et al., 2012). Figure 6 shows the levels of lipids in maize grains, as a function of the reduction of water content and the increase in drying air temperature.

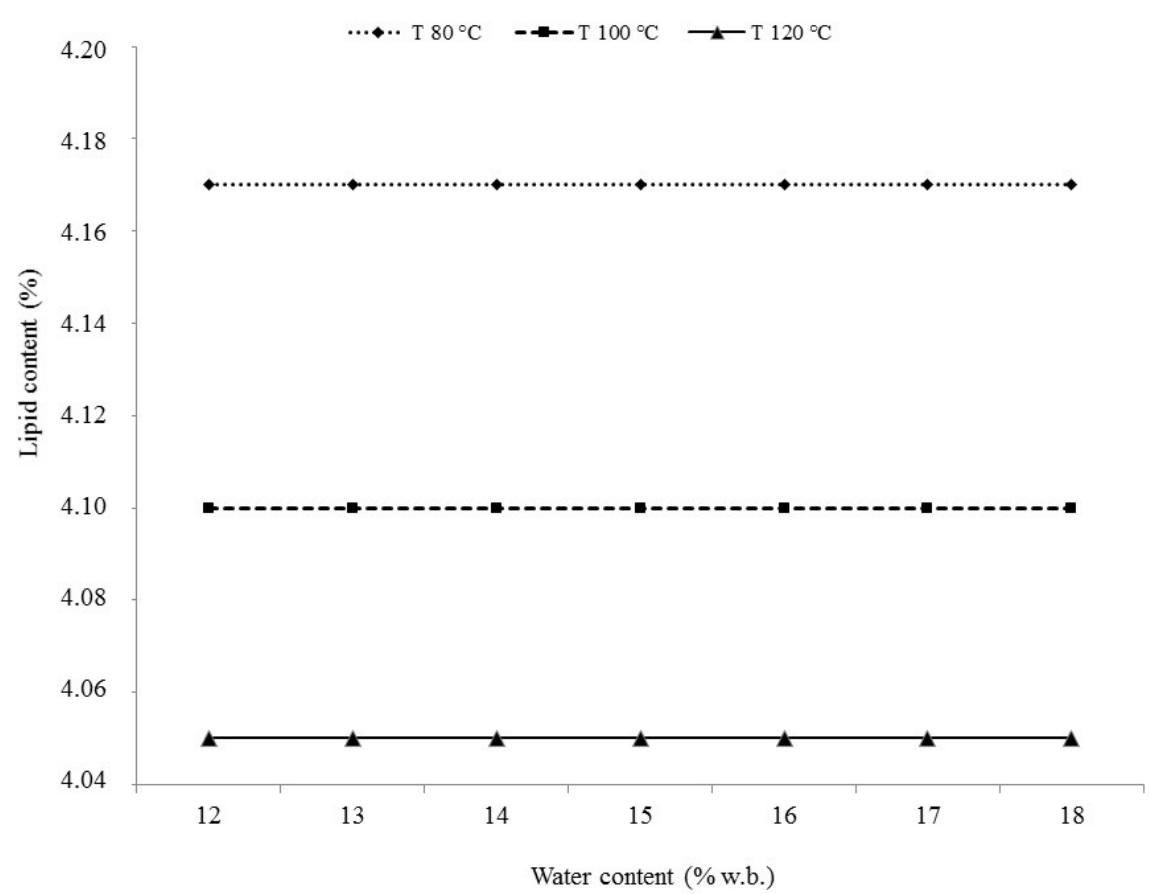

Figure 6. Lipid content in maize grains dried at different air temperatures and water contents. 
The analysis of the results showed statistical differences $\quad(\mathrm{P}<0.05)$ between drying air temperatures, and non-significant differences between water contents. The increase in drying air temperature reduced the levels of lipids of maize grains, regardless of the water content of grains. The increase in drying air temperatures results in an increase in the percentage of grains with cracks; combined with the other effects of drying, they negatively affect the physical-chemical quality of grains (MENEZES et al., 2012). The six-month storage of maize grains in different environments (Figure 7) produced even more significant effects on lipid content because the environment at $23{ }^{\circ} \mathrm{C}$ accelerated the process of grain deterioration, thus reducing lipid content. This process was even more intensive for grains dried at higher temperatures. However, the storage in the refrigerated environment maintained the initial characteristics of lipid content.

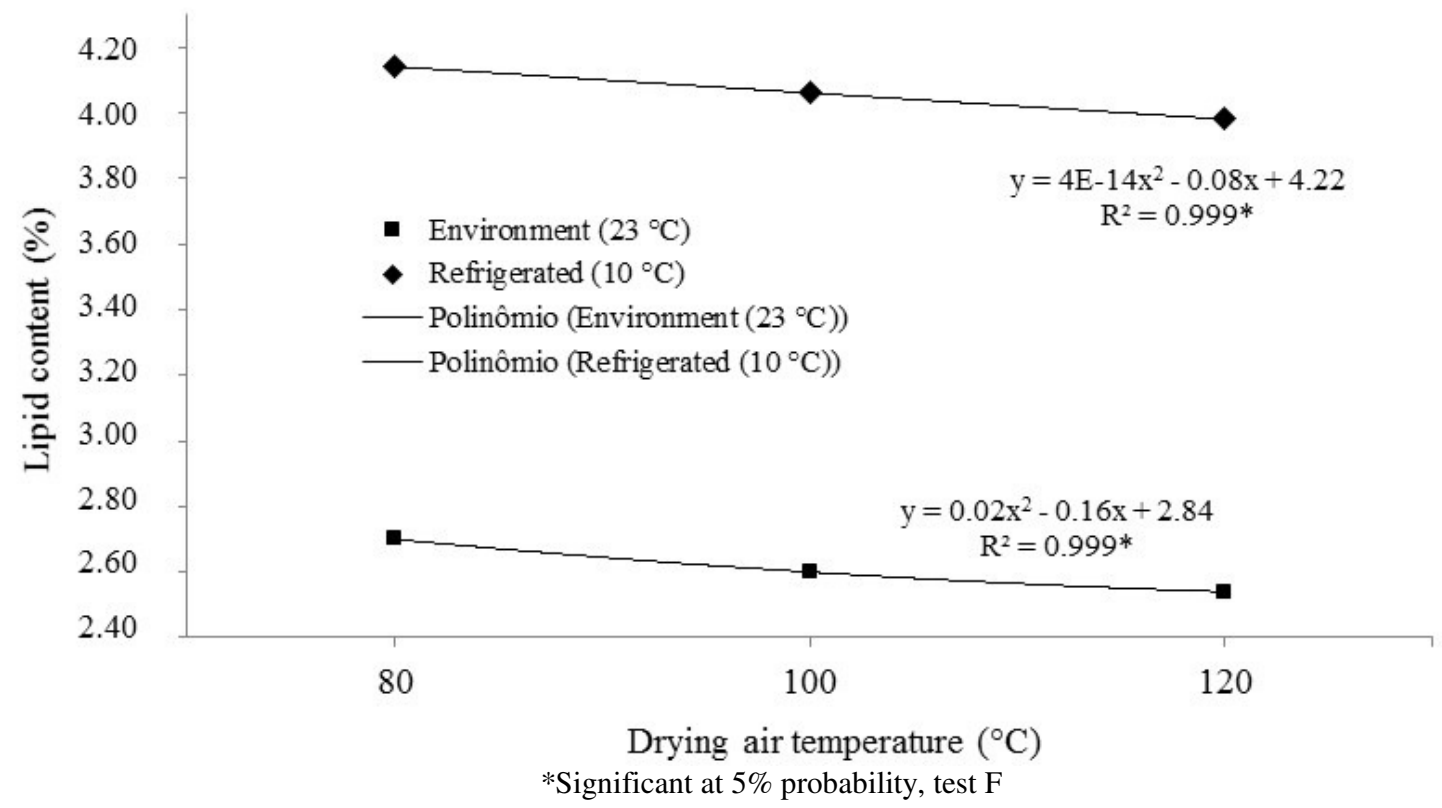

Figure 7. Lipid content in maize grains after drying at different air temperatures and storage in different environments.

As a general rule, the increase in temperature by $1{ }^{\circ} \mathrm{C}$ can accelerate the breathing of the mass of grains by 2 to 3 times up to a certain limit, until breathing ceases at very high temperatures, as a result of the destructive effects of high temperatures on enzymes, causing greater structural damage on grains (FORTI et al., 2010; HUIJGEN et al., 2014).

The increasing drying air temperature from 80 to $120{ }^{\circ} \mathrm{C}$ increased the grain mass temperature of 40 to $50{ }^{\circ} \mathrm{C}$, causing thermal damage through fissures, cracks, fermentation in the grains, resulting in degradation of cellular tissue, reducing the physical-chemical constituents in grain observed by reducing the lipid content. This process predisposes the grains action of lipase enzymes and consequent increased acidity grease. The reduction in storage air temperature $\left(10^{\circ} \mathrm{C}\right)$ decreased the temperature of the grain mass $\left(8^{\circ} \mathrm{C}\right)$, reducing deterioration of cell tissues while minimizing effects drying with stabilizing the lipid content, whereas the conditions storage ambient air temperature $\left(23{ }^{\circ} \mathrm{C}\right)$, the respiratory process of the grain mass increased, causing a higher exchange of heat and water between the mass of grains and the air storage environment, causing most of the grain structure, and reduced lipid content (Figure 7).

Similar results were observed by other authors in drying and storage studies. ALENCAR (2009) observou que the levels of lipids in grains stored at 20,30 and $40{ }^{\circ} \mathrm{C}$, with three water contents $(11.2 \%, 12.8 \%$ and $14.8 \%)$ were evaluated. They found that the levels of lipids were reduced as water content increased. The same authors stated that the decrease in lipid content was significant only when the grains were stored with a water content of $14.8 \%$ under the temperatures of 30 and $40{ }^{\circ} \mathrm{C}$, i.e. at lower temperatures $\left(20^{\circ} \mathrm{C}\right)$, the levels of lipids tend to increase. Other author verified the influence of temperature and period of storage on the lipid content of rice grains (ZHOU et al., 2002). They found that, while in grains stored at $35^{\circ} \mathrm{C}$ there was a significant decrease of lipid content, the same did not happen to grains stored at $5{ }^{\circ} \mathrm{C}$ after 12 months. 
In other studies performed with grain storage, there were changes in oil content and acidity index of grains. Working with the storage of processed rice grains, found an increase in the rate of free fatty acids after four months' storage (PARK et al., 2012). They also reported an increase in acidity in the storage of maize under different temperature conditions (PARAGINSKI et al., 2015). The crude protein serves as the primary source of carbon and nitrogen for the growth and metabolism of fungi (SCHUH et al., 2011; PASCHOS et al., 2015). In the system at low temperatures of storage, even with low levels of oxygen, growth of fungi may occur. This may also lead to an initial increase of crude protein of grains, but to a lower extent when compared with the system at high storage temperatures. However, the same authors claimed that heat and moisture exchanges are less intense than in airtight storage. The high temperatures cause chemical constituents of grains, such as lipids, carbohydrates and proteins (SCHUH et al., 2011; GARCÍA et al., 2014). Figures 8, 9 and 10 show that the reductions in water contents in grains dried with air temperatures of 80,100 and $120{ }^{\circ} \mathrm{C}$, respectively, influenced the increase in starch concentration and final ethanol yield.

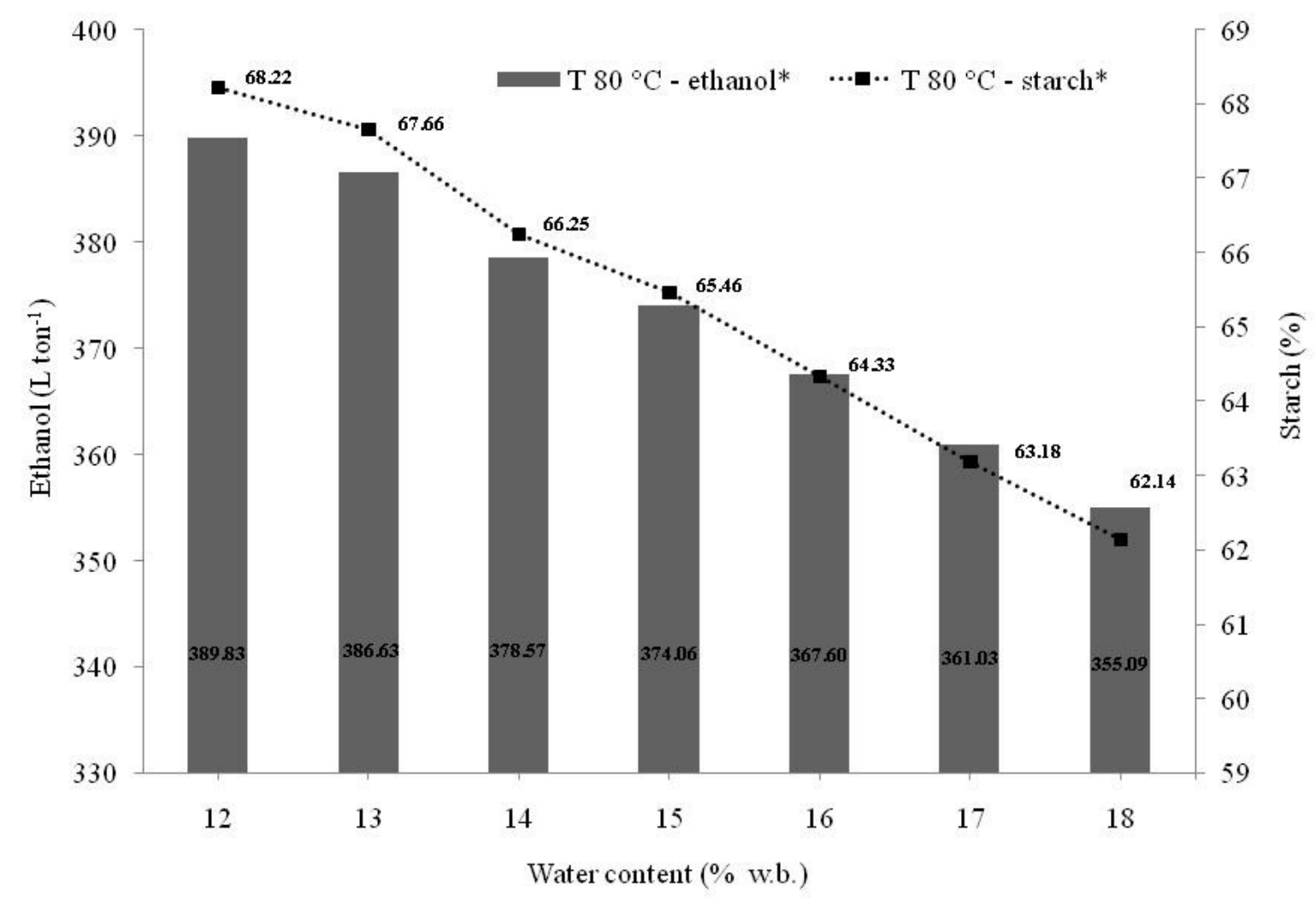

*Significant at $5 \%$ probability, test $\mathrm{F}$

Figure 8. Starch percentage and ethanol yield in maize grains dried at air temperature of $80{ }^{\circ} \mathrm{C}$ for different water contents. 


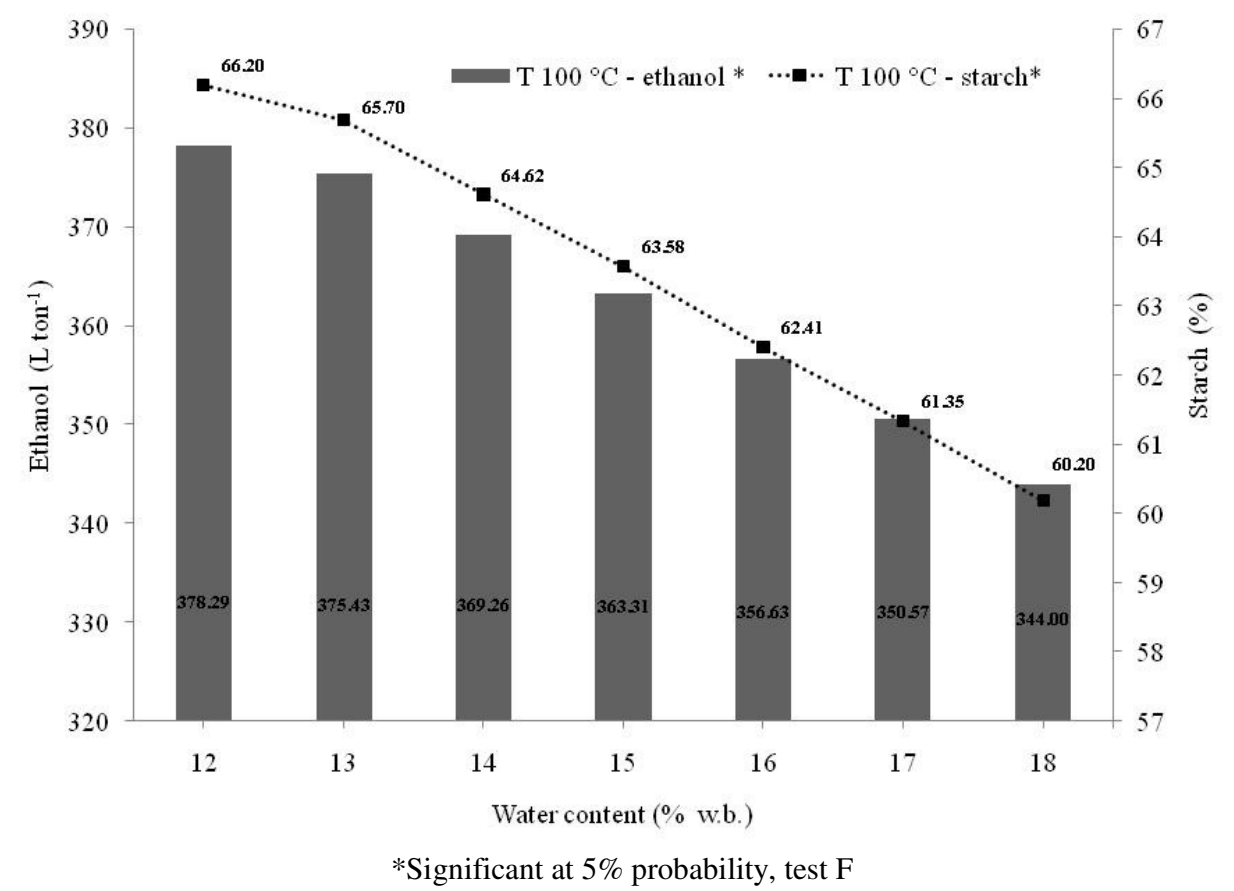

Figure 9. Starch percentage and ethanol yield in maize grains dried at air temperature of $100{ }^{\circ} \mathrm{C}$ for different water contents.

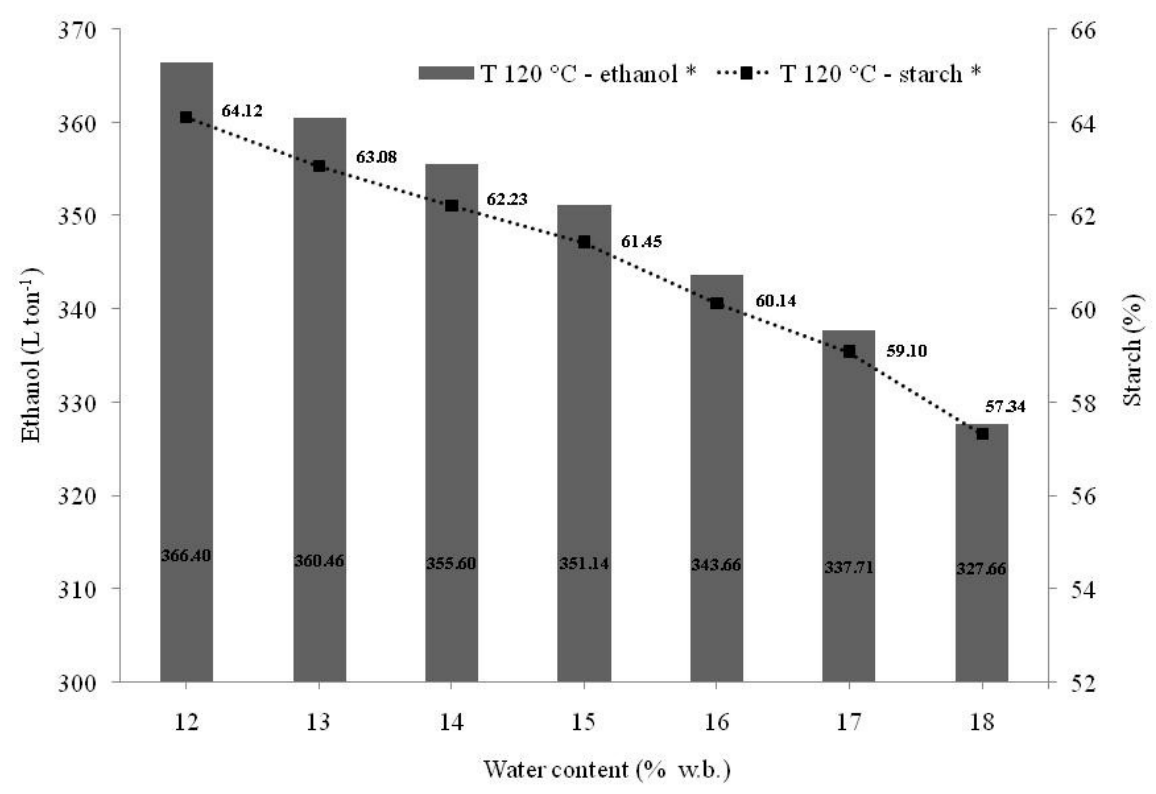

*Significant at $5 \%$ probability, test $\mathrm{F}$

Figure 10. Starch percentage and ethanol yield in maize grains dried at air temperature of $120{ }^{\circ} \mathrm{C}$ for different water contents.

This increase was approximately 6 to $8 \%$ of starch and 34 liters of ethanol, when grains were dried from 18 to $12 \%$ (w.b.) of moisture. The use of high temperatures in drying can compromise the physical and chemical characteristics of grains, causing oil darkening, protein denaturation and starch gelatinization. Evaluating starch content in white oat with drying temperature of $25,50,75$ and $100{ }^{\circ} \mathrm{C}$, it was found a reduction in starch content with increased drying temperature (OLIVEIRA et al., 2010). The reduction of starch and soluble dietary fiber can be explained by the use of high temperatures that lead to the complexation of these compounds (GUTKOSKI et al., 2000; LAMMENS et al., 2012; BROWN et al., 2013).

The percentage reduction of the starch has occurred due to the change of the endosperm that is affected when the beans are heated at temperatures above $45{ }^{\circ} \mathrm{C}$ (Figures 9 and 10). The drying air temperatures exceeding $60{ }^{\circ} \mathrm{C}$ resulted in lower 
viscosity and yield in starch extraction process, reducing swelling power of the starch. The high temperature drying conferred the starch granules a stiffness which reduced swelling power and the solubility rates of water during the gelling process, and these structural changes in the starch granules affect the pulp handling characteristics, reducing maximum peak viscosity and the breakdown of the sample during the heating period, however increased the initial gelatinization temperature. The corn grains storage reduced starch yield of the extraction during grinding by wet due to starch degradation and interactions between the starch and other grain components caused by conditions of higher temperature storage environment $\left(23^{\circ} \mathrm{C}\right)$ and the mass of grains $\left(18^{\circ} \mathrm{C}\right)$.

In the comparative evaluation between drying air temperatures (Figures 11 and 12), it was even more evident that the increase in drying air temperatures influenced starch percentage and ethanol yield of corn grains.

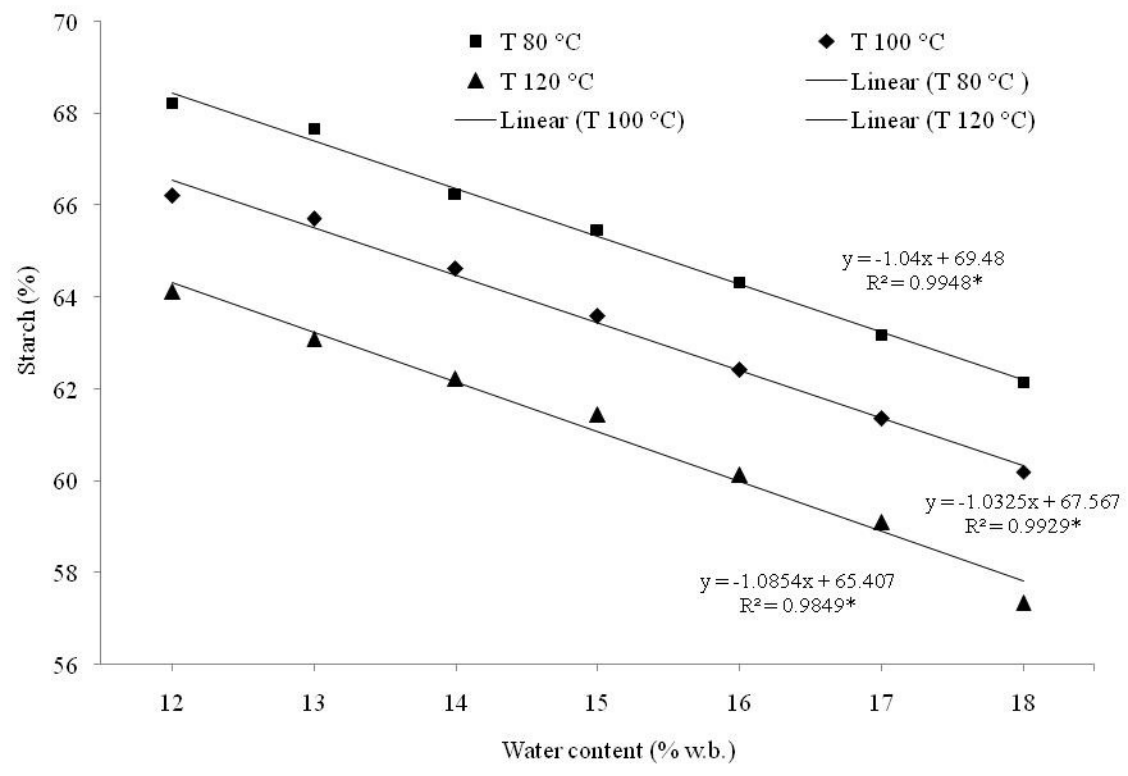

*Significant at $5 \%$ probability, test $\mathrm{F}$

Figure 11. Starch percentage of maize grains for the different drying air temperatures and water contents.

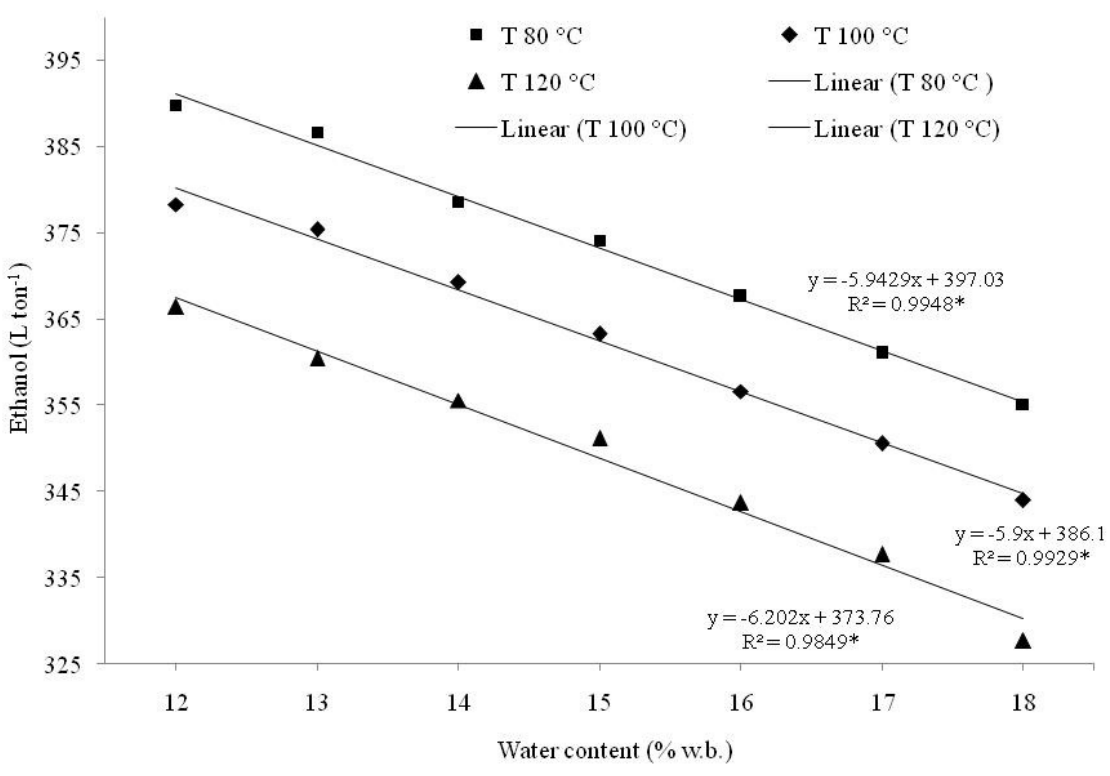

*Significant at $5 \%$ probability, test $\mathrm{F}$

Figure 12. Ethanol yield in maize grains for different drying air temperatures and water contents. 
The ethanol production is directly related to income and extraction of starch from corn kernels, observed in the Figures 8, 9, 10, 11 and 12. When drying air temperature was $80^{\circ} \mathrm{C}$, at the end of the process, starch percentage of maize grains was $68.22 \%$ and ethanol yield was $389.83 \mathrm{~L} \mathrm{ton}^{-1}$ of grains, while for drying air temperature of $100{ }^{\circ} \mathrm{C}$, starch percentage and ethanol yield were $66.20 \%$ and $378.29 \mathrm{~L}^{-1}$ of grain, respectively. In contrast, for drying air temperature of $120{ }^{\circ} \mathrm{C}$, starch percentage and ethanol yield were reduced to $64.12 \%$ and $366.40 \mathrm{~L} \mathrm{ton}^{-1}$ of grains, respectively. Storage conditions, after six months, combined with drying air temperature of the grains, had a significant influence $(\mathrm{P}<0.05)$ on the results of starch and ethanol for the maize grains (Figures 13 and 14).

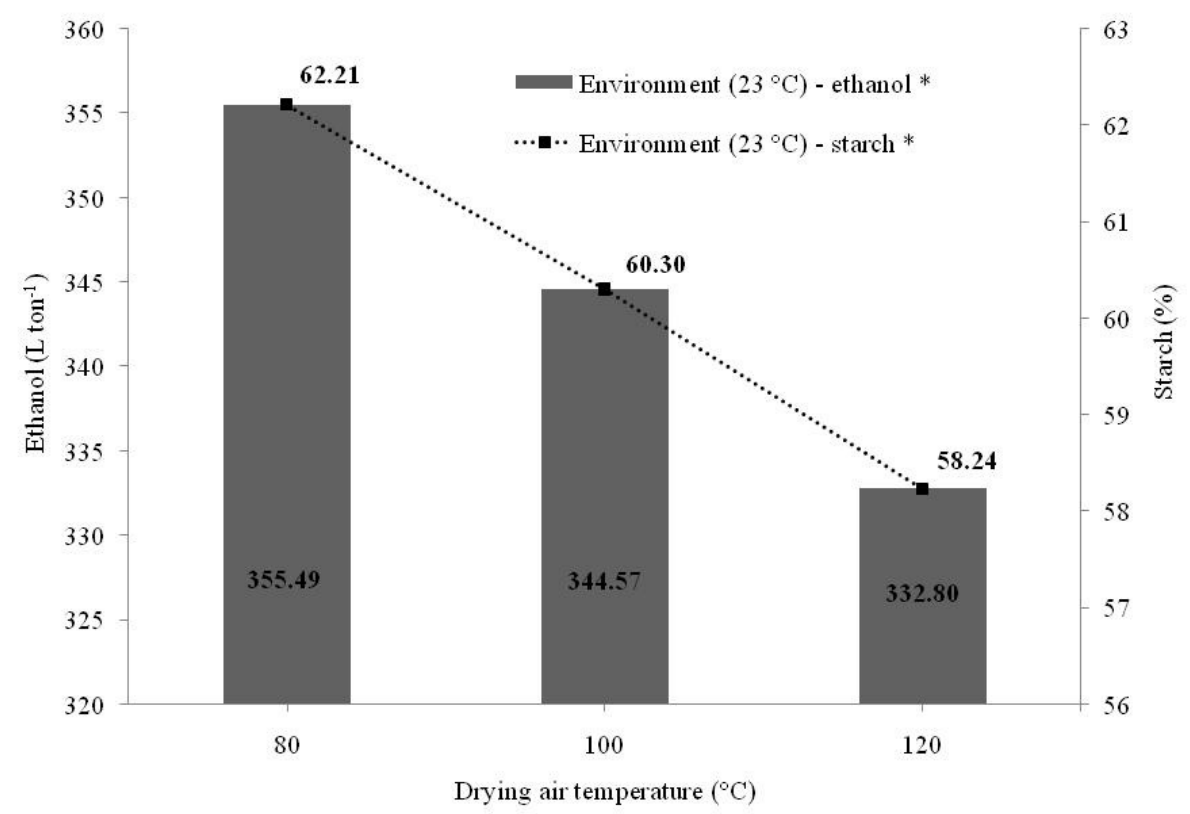

*Significant at $5 \%$ probability, test $\mathrm{F}$

Figure 13. Starch percentage and ethanol yield in maize grains dried at different drying air temperatures and storage condition of $23{ }^{\circ} \mathrm{C}$.

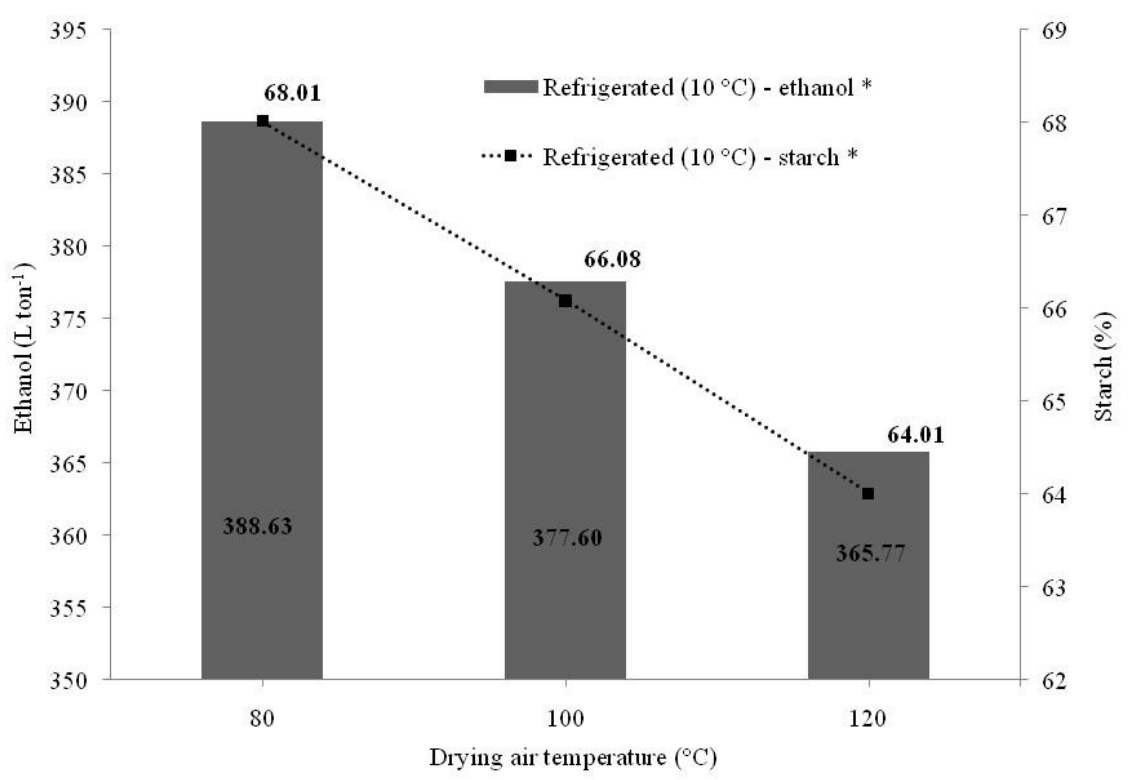

*Significant at $5 \%$ probability, test $\mathrm{F}$

Figure 14. Starch percentage and ethanol yield in maize grains dried at different drying air temperatures and storage condition of $10{ }^{\circ} \mathrm{C}$. 
For the condition of storage in a natural environment $\left(23{ }^{\circ} \mathrm{C}\right)$, starch percentage ranged from 58.24 to $62.21 \%$, depending on the drying air temperature used for the grains, i.e., starch percentage decreased as drying air temperature increased. The same trend took place for ethanol yield, which ranged from 332.80 to $355.49 \mathrm{~L} \mathrm{ton}^{-1}$ of grains. In the storage of grains in the refrigerated environment $\left(10{ }^{\circ} \mathrm{C}\right)$, starch percentage (64.01 to $68.01 \%$ ) and ethanol yield (365.77 to $388.63 \mathrm{~L} \mathrm{ton}^{-}$ ${ }^{1}$ of grains) were higher. Also, variations by the effects of drying were proportionally equal, for both storage conditions. A comparison between the storage conditions (Figures 15 and 16) showed that in the natural environment $\left(23{ }^{\circ} \mathrm{C}\right)$, starch percentage and ethanol yield were lower than in the refrigerated storage, under the same conditions of drying air temperature, while the difference between storage conditions were approximately additional $6 \%$ starch and $33 \mathrm{~L} \mathrm{ton}^{-1}$ of grains for refrigerated storage at $10{ }^{\circ} \mathrm{C}$.

In a study conducted with maize grains, ethanol yields were around 395 liters per tonnes of grain (SOBRINHO, 2012). However, the use of high quality maize grains led to average ethanol yields of $410 \mathrm{~L}$ of per tonne (USIMAT, 2015). The effects observed at post-harvest for industrial ethanol yield, in the present study, can provide relevant insights to the productive chain of ethanol in Brazil, especially industries, towards a more critical analysis for investment in storage units and adoption of appropriate post-harvest techniques, in order to obtain high quality raw material throughout the year and achieve greater production of ethanol.

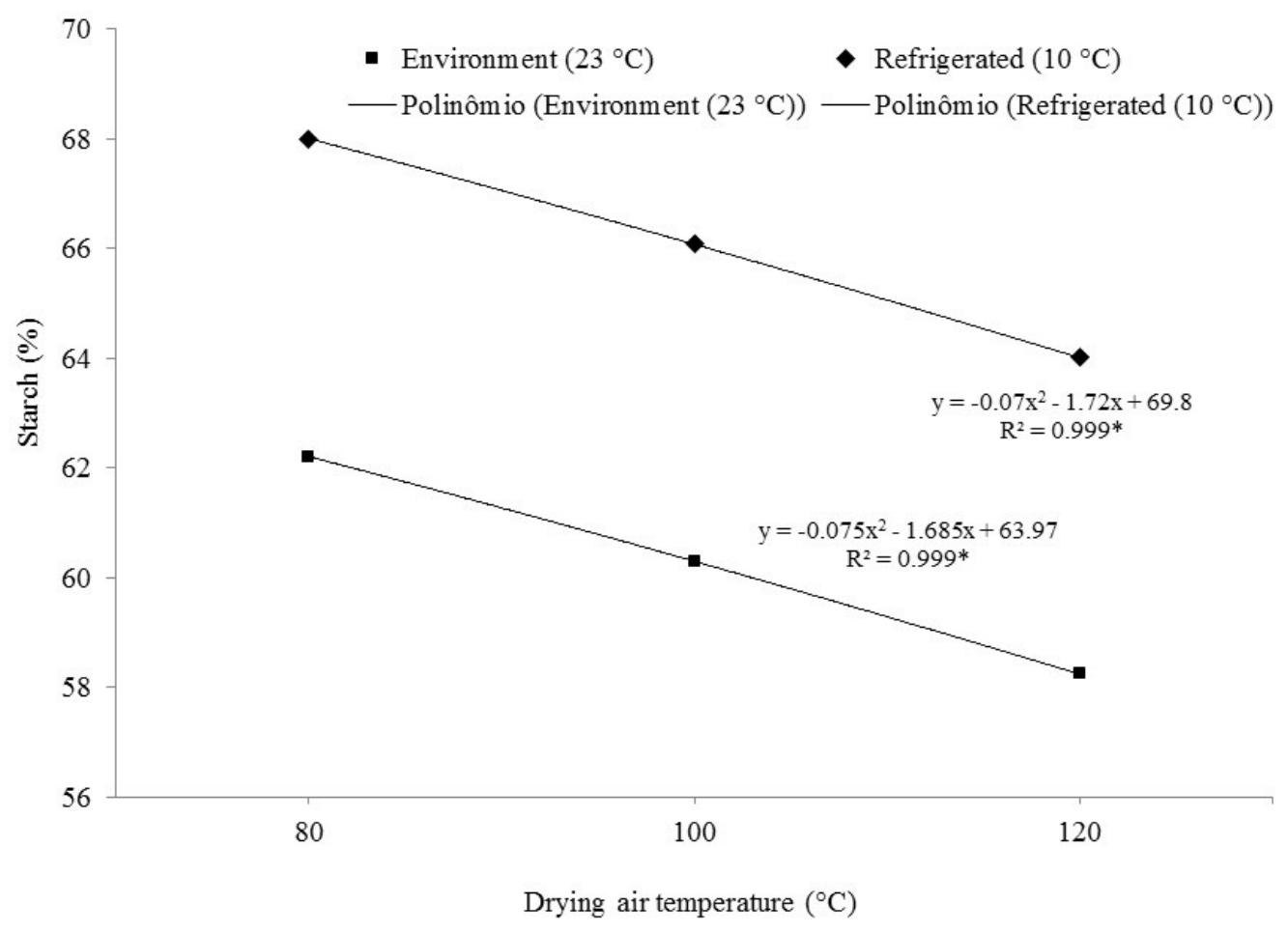

*Significant at $5 \%$ probability, test $\mathrm{F}$

Figure 15. Evaluation of starch percentage (\%) in maize grains for different drying air temperatures and storage conditions. 


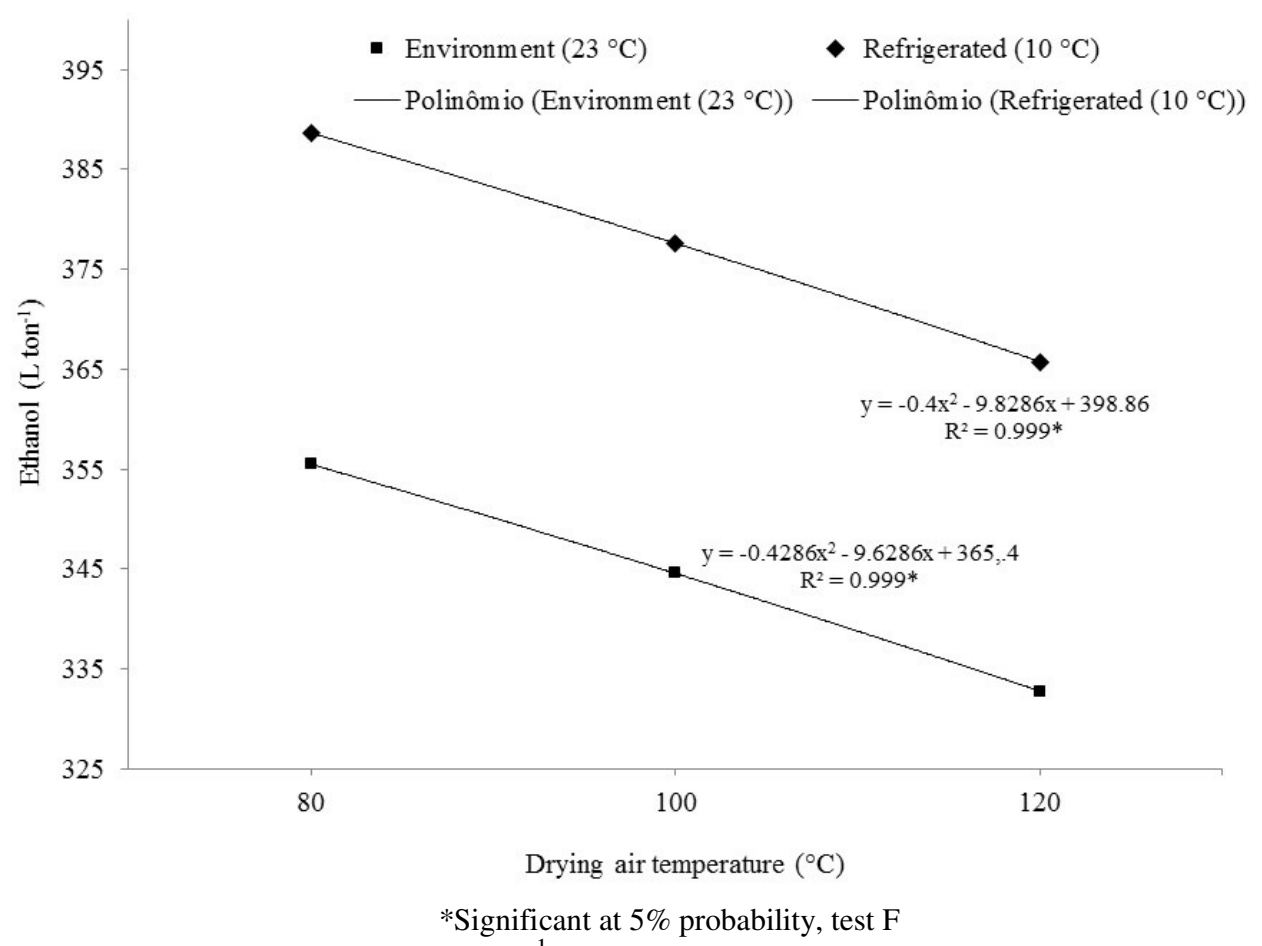

Figure 16. Assessment of ethanol yield $\left(\mathrm{L} \mathrm{ton}^{-1}\right)$ in maize grains for different drying air temperatures and storage conditions.

\section{CONCLUSIONS}

The increase in drying air temperature reduced lipid content and starch percentage, decreasing ethanol yield to $38.74 \mathrm{~L} \mathrm{ton}^{-1}$ of grain.

Storage under refrigeration at $10{ }^{\circ} \mathrm{C}$ was favorable for the maintenance of lipid levels $(+2 \%)$, starch percentage $(6 \%)$ and ethanol yield $\left(33 \mathrm{~L} \mathrm{ton}^{-1}\right.$ of grains).

For production conditions in Brazil, grains should be dried at air temperatures up to $80^{\circ} \mathrm{C}$, and storage must be performed under refrigerated air up to $10^{\circ} \mathrm{C}$ for quality assurance of maize grains in the fallow period and, therefore, increased ethanol production in the industry.

\section{ACKNOWLEDGEMENTS}

The authors would like to thank CAPES (Coordination for the Improvement of Higher Education Personnel), CNPq (National Council for Scientific Technological Development), FUNDECT-MS (Foundation for the Support and Development of Education, Science and Technology from the State of Mato Grosso do Sul), and the Federal University of Mato Grosso do Sul for their financial support.

RESUMO: O objetivo do presente trabalho foi avaliar os efeitos da secagem e as condições de temperatura do ar e armazenamento utilizadas no Brasil na qualidade de grãos de milho (Zea mays L.) para a produção de etanol. O experimento foi instalado em delineamento inteiramente casualizado, em arranjo fatorial (3x2x2) (secagem a temperatura do ar de 80,100 e $120^{\circ} \mathrm{C}$ vs. condições de ambiente de armazenamento de $23^{\circ} \mathrm{C} / 60 \%$ RH e resfriamento de $10{ }^{\circ} \mathrm{C} / 40 \%$ RH vs. tempo de armazenamento de zero e seis meses). Os grãos de milho foram colhidos com um teor de água de $18,0 \%$ (w.b.). Em seguida, os grãos foram secos em estufa de convecção / forçada de ar a diferentes temperaturas, até que o teor de água atingiu 12\% (w.b.). Em seguida, os grãos foram armazenados. Concluiu-se que o aumento da temperatura do ar de secagem reduziu os teores de lípidos e a percentagem de amido, diminuindo o rendimento de etanol a $38,74 \mathrm{~L}^{-1}$ de $^{-1}$ grãos. O armazenamento sob refrigeração, a $10{ }^{\circ} \mathrm{C}$ foi favorável para a manutenção dos níveis de lípidos $(+2 \%)$, percentagem de amido (6\%) e rendimento de etanol (33 $\mathrm{L} \mathrm{ton}^{-1}$ de grãos). Assim, considerando as condições de produção e clima no Brasil, os grãos devem ser secos nas temperaturas do ar de até $80{ }^{\circ} \mathrm{C}$ e o armazenamento deve ser realizado sob refrigeração do ar até $10{ }^{\circ} \mathrm{C}$ para garantir a qualidade dos grãos de milho na estação seca e, portanto, um aumento da produção de etanol na indústria.

KEYWORDS: Biocombustíveis. Indústria. Produção. Zea mays L. 


\section{REFERENCES}

AACC. American Association of Cereal Chemists. Approved Methods of AACC 30-20, 9ed. St. Paul., 1995.

ABIMILHO. Associação Brasileira das Indústrias do milho: estimativa de oferta e demanda. 2014. Disponível em: <http://www.abimilho.com.br/estatistica>. Acesso em: 08 de agosto de 2014.

ALENCAR, E. R. de; FARONI, L. R. D.; LACERDA FILHO, A. F.; PETERNELL, L. A.; COSTA, A. R. Qualidade dos grãos de soja armazenados em diferentes condições. Revista Brasileira de Engenharia Agrícola e Ambiental, v. 13, n. 5, p. 606-613, 2009. http://dx.doi.org/10.1590/S1415-43662009000500014

AOAC. Association of Official Analytical Chemists. Official methods of analysis of the Association of Official Analytical Chemists. 17. ed. Gaithersburg, Maryland: AOAC, 2000, p. 4-12.

BACHKNUDSEN, K. E. Carbohydrate and lignin contents of plant materials used in animal feeding. Animal Feed Science and Technology, v. 67, n. 4, p. 319-338, 1997. doi:10.1016/S0377-8401(97)00009-6

BRAGATTO, S. A; BARELLA, W. D. Otimização do Sistema de Armazenagem de Grãos: Um estudo de caso. 2009. Disponível em: <www.abepro.org.br/biblioteca/ENEGEP2001_TR21_0163.pdf> Acesso em: $14 / 05 / 2015$.

BEMILLER; WHISTLER. Starch: Chemistry and technology. Third edition. Food Science and Technology, 2009.

BRAZIL. Ministério da Agricultura e Reforma Agrária. Secretaria Nacional de defesa Agropecuária. Classificação física de grãos de milho, Brasília, 2012, 395p.

BROWN, T. R; BROWN, R. C. A review of cellulosic biofuel commercial-scale projects in the United States. Biofuel Bioprod Bioref, v. 7, n. 3, p. 235-245, 2013. doi: 10.1002/bbb.1387

CORADI, P. C.; LACERDA FILHO, A. F. de; CHAVES, J. B. P.; MELO, E. C. Quantification of physical losses products in a plant of feed. Engenharia na Agricultura, v. 23, n. 2, p. 105-118, 2015. doi: $10.13083 / 1414-3984$

COSTA, L. M.; RESENDE, O.; SOUSA, K. A.; GONÇALVES, D. N. Coeficiente de difusão efetivo e modelagem matemática da secagem de sementes de crambe. Revista Brasileira Engenharia Agrícola e Ambiental, v. 15, n. 10, p. 1089-1096, 2011. http://dx.doi.org/10.1590/S1415-43662011001000014

DINNEEN, B. Ethanol Industry Outlook. [Online]. 2015. Renewable Fuels Association. Available at: http://www.ethanolrfa.org/ [accessed 10 August 2015].

FAO. 2012. Food and Agricultural Organization.

FORTI, V. A.; CÍCERO, S. M.; PINTO, T. L. F. Avaliação da evolução de danos por 'umidade' e redução do vigor em sementes de soja, cultivar TMG 113-RR, durante o armazenamento, utilizando imagens de raio X e testes de potencial fisiológico. Revista Brasileira de Sementes, v. 32, n. 3, p. 123-133, 2010.

http://dx.doi.org/10.1590/S0101-31222010000300014

GARCÍA, A.; CARA, C.; MOYA, M.; RAPADO, J.; PULS, J.; CASTRO, E.; MARTÍN, C. Dilute sulphuric acid pretreatment and enzymatic hydrolysis of Jatropha curcas fruit shells for ethanol production. Industrial Crops and Products, v. 53, n. 1, p. 148-153, 2014. doi: 10.1016/j.indcrop.2013.12.029

GOLDEMBERG, J.; NIGRO, F. E. B.; COELHO, S. T. Bioenergia no estado de São Paulo: Situação atual, perspectivas, barreiras e propostas, São Paulo: Imprensa Oficial do Estado de São Paulo, 2008, 152p. 
GUTKOSKI, L. C.; PEDÓ, I. Aveia: composição química, valor nutricional e processamento, São Paulo: Varela, 2000, 192p.

HASJIM, J.; LEE, S.; HENDRICH, S.; SETIAWAN, S.; AI, Y.; JANE, J. Effects of a novel resistant-starch on postprandial plasma-glucose and insulin responses. Cereal Chemistry, v. 87, n. 4, p. 257-262, 2010. http://dx.doi.org/10.1094/CCHEM-87-4-0257

HETTINGA, W. G.; JUNGINGER, H. M.; DEKKER, S. C.; HOOGWIJK, M.; MCALOON, A. J.; HICKS, K. B. Understanding the reductions in US corn ethanol production costs: An experience curve approach. Energy Policy, v. 37, n. 1, p. 90-203, 2009. doi:10.1016/j.enpol.2008.08.002

HUIJGEN, W. J.; TELYSHEVA, G.; ARSHANITSA, A.; GOSSELINK, R. J. A.; WILD, P. J. Characteristics of wheat straw lignins from ethanol-based organosolv treatment. Industrial Crops and Products, v. 59, n. 1, p. 85-95, 2014. doi:10.1016/j.indcrop.2014.05.003

KWIATKOWSKI, J. R.; MCALOON, A. J; TAYLOR, F.; JOHNSTON, D. B. Modeling the process and costs of fuel ethanol production by the corn dry-grind process. Industrial Crops Products, v. 23, n. 3, p. 288-296, 2006. doi:10.1016/j.indcrop.2005.08.004

LAMMENS, T. M.; FRANSSEN, M. C. R.; SCOTT, E. L.; SANDERS, J. P. M. Availability of protein-derived amino acids as feedstock for the production of bio-based chemicals. Biomass and Bioenergy, v. 44, n. 1, p. 168-181, 2012. doi:10.1016/j.biombioe.2012.04.021

LEE, J. H.; CHO, K. M. Changes occurring in compositional components of black soybeans maintained at room temperature for different storage periods. Food Chemical, v. 131, n. 1, p. 161-169, 2012.

doi:10.1016/j.foodchem.2011.08.052

MENEZES, N. L.; CÍCERO, S. M.; VILLELA, F. A.; BORTOLOTTO, R. P. Using X-Rays to evaluate fissures in rice seeds dried artificially. Revista Brasileira de Sementes, v. 34, n. 1, p. 70-77, 2012. http://dx.doi.org/10.1590/S0101-31222012000100009

OLIVA, A. C. E.; BIAGGIONI, M. A. M.; CAVARIANI, C. Efeito imediato do método de secagem na qualidade de sementes de crambe. Energia na Agricultura, v. 27, n. 3, p. 16-30. 2012. http://dx.doi.org/10.17224/EnergAgric.2012v27n3p16-30

OLIVEIRA, L. D. A. C.; GUTKOSK, L. C.; ELIAS, M. C.; MAZZUTTI, S.; AOSANI, E.; ROCHA, J. C. da. Efeito da temperatura de secagem na qualidade de grãos de aveia branca. Ciência \& Agrotecnologia, v. 34, n. 2, p. 313-319, 2010. http://dx.doi.org/10.1590/S1413-70542010000200007

PARAGINSKI, R. T.; ROCKENBACH, B. A.; SANTOS, R. F. dos; ELIAS, M. C.; OLIVEIRA, M. de. Qualidade de grãos de milho armazenados em diferentes temperaturas. Revista Brasileira de Engenharia Agrícola e Ambiental, v. 19, n. 2, p. 358-363, 2015.

http://www.ccarevista.ufc.br/seer/index.php/ccarevista/article/view/643

PARK, C.; KIM, Y.; PARK, K.; KIM, B. Changes in physicochemical characteristics of rice during storage at different temperatures. Journal Stored Products Research, v. 48, n. 1, p. 25-29, 2012. doi:10.1016/j.jspr.2011.08.005

PASCHOS, T.; XIROS, C.; CHRISTAKOPOULOS, P. Simultaneous saccharification and fermentation by cocultures of Fusarium oxysporum and Saccharomyces cerevisiae enhances ethanol production from liquefied wheat straw at high solid content. Industrial Crops Products, v. 76, n. 1, p. 793-802, 2015. doi:10.1016/j.indcrop.2015.07.061 
RIGUEIRA, R. J. A.; LACERDA FILHO, A. F.; VOLK, M. B. S. Avaliação da qualidade do feijão armazenado em ambiente refrigerado, Alimentos e Nutrição, v. 20, n. 4, p. 649-655, 2009. http://servbib.fcfar.unesp.br/seer/index.php/alimentos/article/viewArticle/1242

SCHUH, G.; GOTTARDI, R.; FERRARI, E. F.; ANTUNES, L. E. G.; DIONELLO, R. G. Efeitos de dois métodos de secagem sobre a qualidade físico-química de grãos de milho safrinha-RS, armazenados por 6 meses, Semina: Ciências Agrárias, v. 32, n. 1, p. 235-244, 2011. http://dx.doi.org/10.5433/16790359.2011v32n1p235

SOBRINHO, P. Processo de produção de etanol de milho: destilaria/usina flex e abordagem descritiva de um novo potencial. CONAB-Companhia Nacional de Abastecimento, Cuiabá, MT. 2012.

ULLMANN, R.; RESENDE, O.; SALES, J. F.; CHAVES, T. H. Qualidade das sementes de pinhão manso submetidas à secagem em diferentes condições de ar. Revista Ciência Agronômica, v. 41, n. 3, p. 442-447, 2010. http://www.ccarevista.ufc.br/seer/index.php/ccarevista/article/view/911

USIMAT. Usina flex de produção de etanol do estado do Mato Grosso. 2015. Usimat produz etanol o ano todo.

WEBER, E. A. Armazenagem agrícola, 2.ed. Editora Guaíba, 2001, 396p.

ZHOU, Z.; ROBARDS, K.; HELLIWELL, S.; BLANCHARD, C. Ageing of stored rice: changes in chemical and physical attributes. Journal Cereal Science, v. 35, n. 1, p. 65-78, 2002. doi:10.1006/jcrs.2001.0418 